\title{
Pseudomonas (Flavimonas) oryzihabitans
}

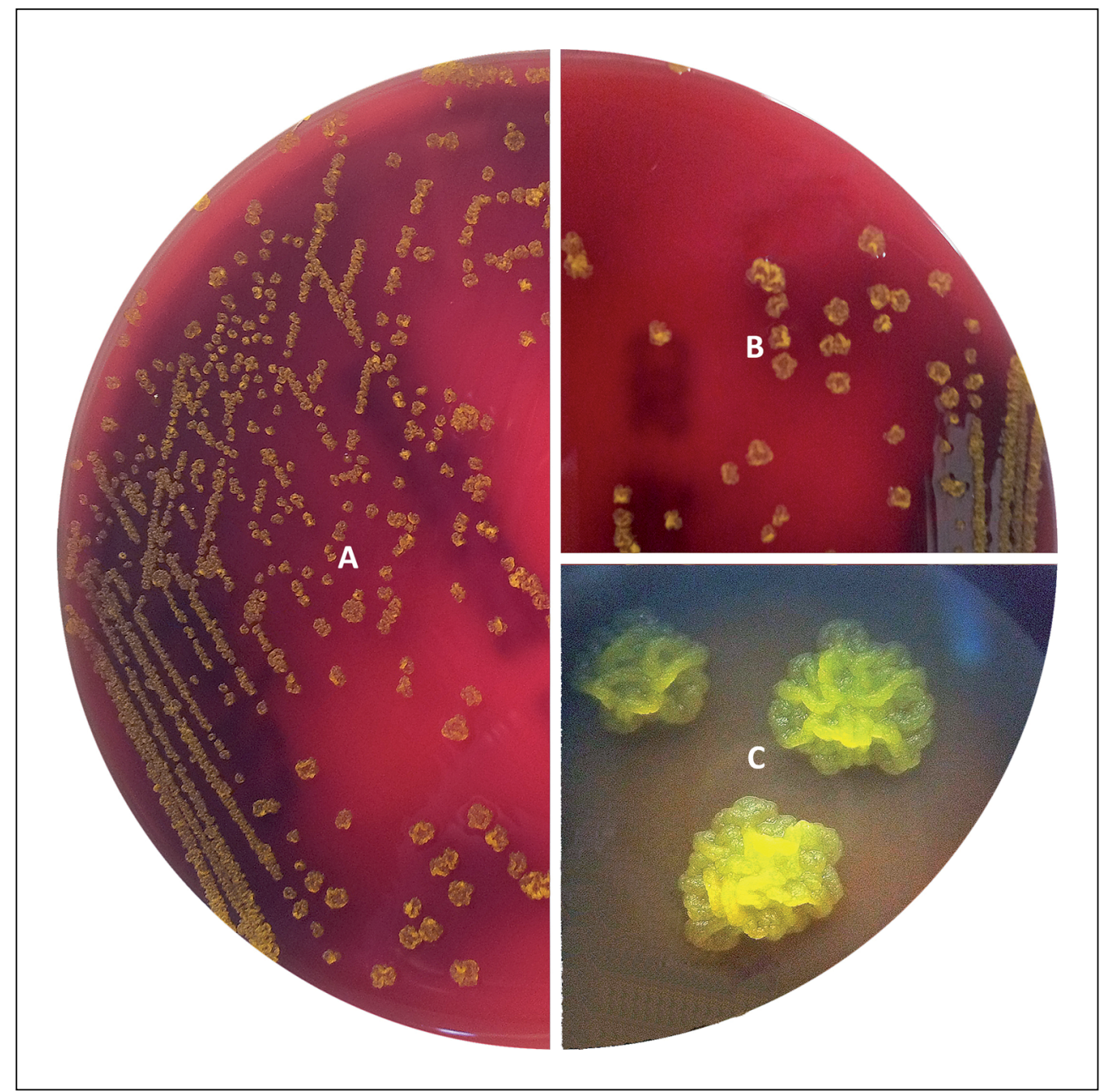

Figura 1. A y B: colonias de Pseudomonas oryzihabitans, en agar sangre a las 48-72 h de incubación. C: colonia bajo observación con lupa estereoscópica donde destaca colonia rugosa y pigmentación amarilla. 


\title{
Pseudomonas (Flavimonas) oryzihabitans
}

Pseudomonas (Flavimonas) oryzihabitans, previamente conocida como Chromobacterium typhiflavum es un bacilo Gram negativo no fermentador en el que aún persisten discrepancias en su taxonomía. Se encuentra dentro del subgrupo de bacilos no fermentadores CDC Ve-2 por sus características bioquímicas; en especial por ser oxidasa negativa fue clasificado dentro del género Flavimonas para diferenciarlo del género Pseudomonas (oxidasa positiva); sin embargo, en 1997 se describe por secuenciación de ARN ribosomal 16S una homología superior a 93\% por lo que se propone que Pseudomonas, Flavimonas y Chryseomonas podrían corresponder a un mismo género. En la actualidad se aceptan ambos géneros.

Pseudomonas oryzihabitans se caracteriza por ser un bacilo Gram negativo que crece bien en medios de cultivo habituales como agar Mac Conkey y agar sangre. No crece a $4^{\circ} \mathrm{C}$ ni a $42^{\circ} \mathrm{C}$ y es aerobio estricto. En medios sólidos, en las primeras $24 \mathrm{~h}$, se observan colonias pequeñas lisas que en 48 a $72 \mathrm{~h}$ se tornan firmes, rugosas, de un tamaño entre 1 y $2 \mathrm{~mm}$ y con un pigmento amarillo característico (Figura 1). No produce hemólisis en agar sangre.

Entre las pruebas de identificación destacan que no fermenta la glucosa, es catalasa positiva, oxidasa negativa y no reduce los nitritos. Las pruebas de descarboxilación de la ornitina, lisina, arginina, esculina, ADNasa y gelatinasa son negativas. La prueba de ureasa es variable. Se encuentra incluida en galerías miniaturizadas de identificación y en la mayoría de los sistemas comerciales automatizados.

Se considera que $P$. oryzihabitans es un agente saprófito aislado típicamente en cultivos de arroz, suelos y aguas estancadas. En el ambiente hospitalario se ha aislado de desagües y equipos de terapia respiratoria. Su aislamiento en muestras clínicas es poco frecuente y se ha descrito como agente de pseudobrotes por contaminación durante la toma de muestra de hemocultivos. Existen reportes de P. oryzihabitans como agente causante de infecciones del sistema nervioso central, bacteriemias asociadas a catéter, peritonitis en pacientes con peritoneodiálisis y en infección de heridas. La mayoría de los casos corresponde a pacientes inmunocomprometidos, con daño hepático, neoplasias o enfermedad renal crónica, aunque se ha descrito también en pacientes inmunocompetentes asociado a uso de dispositivos vasculares.

El perfil de susceptibilidad de esta especie es poco conocido por su aislamiento inhabitual; sin embargo, la mayoría de los reportes coincide en que es susceptible a cefalosporinas de tercera y cuarta generación, piperacilina/tazobactam, carbapenémicos, aminoglucósidos y quinolonas. Es resistente a cefalosporinas de primera y segunda generación y tiene susceptibilidad variable a cotrimoxazol.

\section{Referencias bibliográficas}

1.- Anzai Y, Kudo Y, Oyaizu H. The phylogeny of the genera Chryseomonas, Flavimonas, and Pseudomonas supports synonymy of these three genera. Int J Syst Bacteriol 1997; 47: 249-51.

2.- Woo K S, Choi J L, Kim B R, Kim J E, Kim K H, Kim J M, et al. Outbreak of Pseudomonas oryzihabitans pseudobacteremia related to contaminated equipment in an emergency room of a tertiary hospital in Korea. Infect Chemother 2014; 46: 42-4.

\author{
Francisco Silva \\ Unidad de Microbiología, Servicio de Laboratorio Clínico, \\ Hospital Clínico Universidad de Chile.
}

Correspondencia a: fsilva@hcuch.cl 